\title{
Domain F: Discourse
}

\begin{abstract}
In this chapter, we examine how discourse-or the ways in which language is used to frame debates, policy and action-is a critical domain for agroecology transformations. A range of different types of actors (e.g. politicians, private companies, activists) use a process called 'framing' to convey their interpretation of agroecology where they 'simplify and condense' its complexity to align with their own views and ideologies. We present seven main frames across a spectrum from those that tend to disable a transformative agroecology (e.g. 'feed the world') to those that are most likely to enable political agroecology (e.g. 'food sovereignty'). Notably all of these frames are at times being deployed in both productivist and depoliticized (regime-reinforcing) ways and also as a part of a transformative politics of political agroecology at different times by different actors.
\end{abstract}

Keywords Discourse $\bullet$ Framing $\bullet$ Food sovereignty $\bullet$ Right to food $\bullet$ Definition

Discourse-the ways in which language is used to frame debates, policy and action-is a critical domain in shaping agroecology transformations (Mier y Terán Giménez Cacho et al. 2018). A range of actors with different social status and worldviews engage in debate over the agroecological "terrain of ideas, of theoretical constructs" (Giraldo and Rosset 2018).

(C) The Author(s) 2021

C. R. Anderson et al., Agroecology Now!, https://doi.org/10.1007/978-3-030-61315-0_9 
This carries implications for which pathways for food system transformation are considered socially legitimate and high priority (Dryzek 2013) and thus how they are resourced and supported. Discourse "directly shapes and conditions the policies and actions taken" (Ajates Gonzalez et al. 2018; Lamine 2017; Loconto and Fouilleux 2019; Pimbert 2015), not just the goals, metrics, standards and practices implied when discussing agroecology.

The discourse on agroecology is shaped by producers' organizations and other civil society groups, governments, the Food and Agriculture Organization of the United Nations (FAO) and other multilateral institutions, researchers, media and the private sector. It is thus not surprising that definitions of agroecology and its role vary hugely, even though it is ostensibly a concept and practice that unifies a diversity of actors (Loconto and Fouilleux 2019; Pimbert 2018a; Rivera Ferre 2018). Despite efforts to advance one particular meaning over another, agroecology is malleable and subject to political processes.

This entails a discursive process, 'framing', used to interpret agroecology in a way that simplifies its complexity and emphasizes characteristics that align with a specific agenda (Benford and Snow 2000). By selectively drawing on and interpreting agroecology through the lens of their own cultural values, beliefs and ideologies, particular actors can frame it in ways useful to them (Geels and Verhees 2011; Steinberg 1998). Below we elaborate on seven key discursive frames we have identified as underpinning key debates on agroecology.

Our analysis suggests that these frames each have a different underlying political basis and intention; these render them more or less enabling or disabling of a transformative agroecology. In Fig. 9.1 you will see a spectrum of frames. At the red end are those that tend to disable a transformative agroecology. At the green are those emphasizing the agency of communities and food producers, as well as resonance with local cultures and are supportive of what we have outlined above as a political agroecology. In the middle are the rest: frames that are much more ambiguous in use and potential. Notably all of these frames are at times being deployed in both productivist and depoliticized (regime-reinforcing) ways and also as a part of a transformative politics of political agroecology at different times by different actors. In the following section we discuss each of these seven frames. 


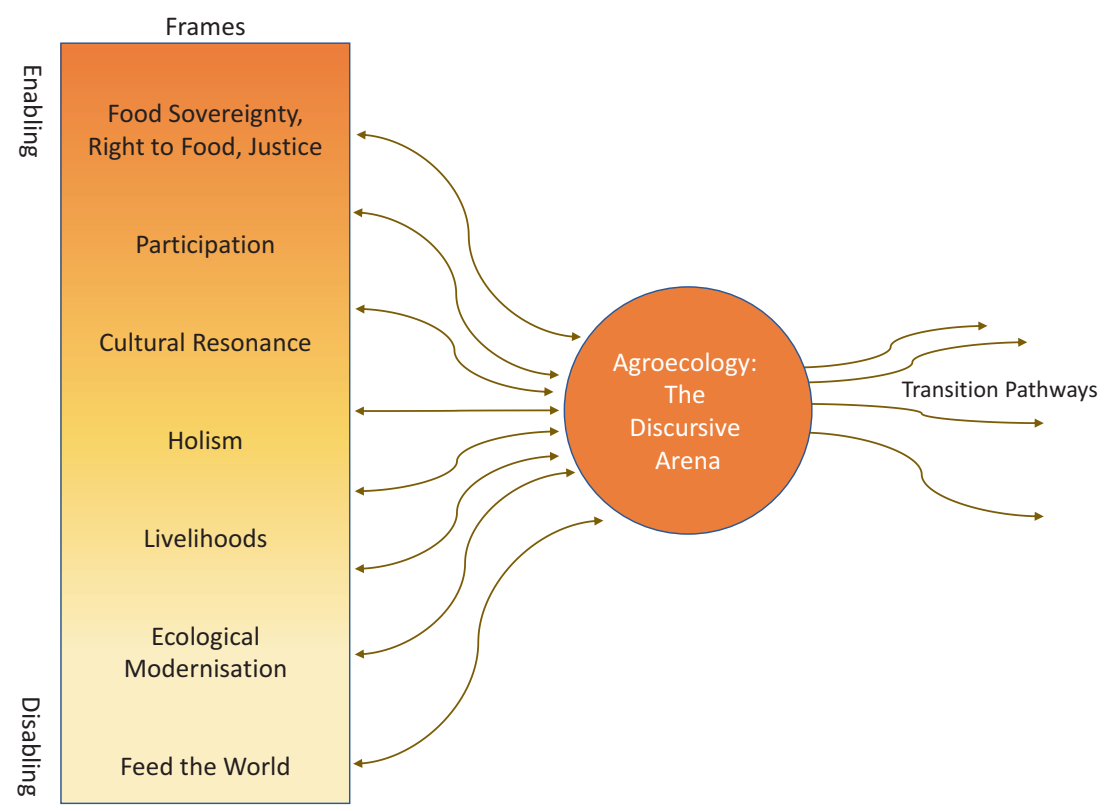

Fig. 9.1 Discourse around agroecology is shaped by different frames that can have both enabling and disabling effects on political agroecology. Some frames, towards the top end of the figure, are much more enabling, while the frames towards the bottom are more likely to have a disabling effect. Other frames, in the middle, are more ambiguous

\section{Food Sovereignty, the Right to Food and Justice}

To advance a transformative agroecology, actors frequently use three related frames that present an enabling set of values, beliefs, principles and worldviews: food sovereignty, human rights and justice. These three intermeshed frames have been developed dialectically along with terms and concepts such as 'transformative agroecology' (Méndez et al. 2015; Levidow 2015, \#360), 'political agroecology' (Méndez et al. 2015) and 'radical, movement-based agroecology' (Holt-Giménez and Altieri 2013). They are rooted in a shared position: that profound political and systemic change is needed to address power relations and advance equity and democracy in the food system.

Many social movements and scholars frame agroecology as an inseparable component of, and pathway towards, food sovereignty (Nyeleni 2015; 
World Forum of Fisher Peoples (WFFP) 2017). While political activities such as protest and advocacy figure large in this arena, agroecology represents an on-the-ground articulation of food sovereignty in the practices of food producers. Specifically, the concept of food sovereignty has been taken up around the world as a political project of food system transformation, rooted in agroecology and the democratization of agriculture and food. As such, it embodies a discourse that affirms the rights of peoples to define their food and agriculture systems as well as their rights to territory and self-determination (World Forum of Fisher Peoples (WFFP) 2017; Nyeleni Movement for Food Sovereignty 2007).

Drawing on both food sovereignty and human rights frameworks, civil society organizations also defend the rights of peoples to healthy and culturally appropriate food produced through ecologically sound and sustainable methods - as well as the rights of food producers to use and manage lands, territories, waters, seeds, livestock and biodiversity (Nyeleni 2015). Thanks to the leadership of social movements and civil society organizations such as La Via Campesina, FIAN International, GRAIN and CETIM, many of these rights are now officially recognized in the UN (2018) Declaration on the Rights of Peasants and Other People Working in Rural Areas (UNDROP). UNDROP radically reframes the dominant legal paradigm by introducing new individual and collective rights to nature and food sovereignty that go beyond the 'right to food' (Claeys 2015). Governments too have been using the human rights frame for agroecology, as it is embedded, for example, in the discourse of New Latin American or New Andean Constitutionalism. These refer to a wave of constitutional reform in Ecuador, Bolivia and Brazil that aim to enhance participatory democracy and recognize the rights of marginalized groups such as indigenous communities.

Finally, civil society organizations and researchers also frame agroecology by associating it with radical forms of justice that challenge the dominant food regime. This frame is sometimes combined with food sovereignty. Researchers, for example, advocate for 'distributive and procedural justice' in relation to agroecology, inquiring respectively into who gets access to what resources as well as who makes decisions about resources, and how (Chris Maughan et al. 2020; Schwendler and Thompson 2017). Further, Michel Pimbert (2018b, p. 31) calls for 'cognitive justice' that recognizes "the right of different forms of knowledge and their associated practices, livelihoods and socio-ecological contexts to coexist" (also see Chap. 5 on the knowledge domain). Introducing yet another aspect Cristian 
Timmermann and Georges Félix (2015) examine the ways in which agroecology enables 'contributive justice'. The latter refers to an agroecological work environment where people can have the opportunity to develop skills and be creative and productive while paying attention to a fairer distribution of meaningful work and tedious tasks. Civil society organizations link agroecology with 'climate justice' (e.g. Friends of the Earth International 2015; La Via Campesina 2018). Finally, movements and researchers are increasingly pointing at the link between agroecology and gender justice, or even a 'feminist agroecology' (Articulação Nacional de Agroecología (ANA) 2018; Bezner Kerr et al. 2019). Some are emphasizing approaches that simultaneously challenge colonialism, racism, capitalism and patriarchy in the food system.

While these frameworks are rarely used in a disabling way, in some cases a depoliticized and sanitized version of these terms is deployed by groups or individuals. The governments of France, Ecuador and Venezuela, for example, have also used the food sovereignty frame in relation to agroecology but have interpreted it narrowly as national or regional food selfsufficiency. This can feed into nationalistic, exclusionary tendencies or become a way to promote national corporate interests. Moreover, the private sector sometimes adopts a rights-based discursive frame when placing intellectual property rights on seeds (see Chap. 4 on rights and access to nature), which runs counter to transformative agroecology.

Finally, many actors use the notion of 'rights' in the context of the neoliberal refrain regarding the right to choose which products or technologies to use. For example, farmers are seen as individual consumers who should have the unimpeded right to use industrial chemicals or consumers should be free to choose the products they like, without acknowledging the multifarious constraints and factors going into such 'choices'. An approach focusing on individual choice obscures all the power dynamics that limit the options available to farmers or citizens.

\section{PARTICIPATION}

Participation and democratization are at the heart of transformative agroecology, implying that the central agency lies with organizations of agricultural producers and citizens. The frame of participation provides a vision and a basis for the process and governance-oriented principles of agroecology (HLPE 2019). 
For example, the International Panel of Experts on Sustainable Food Systems (IPES-Food 2019) points out that by shifting the focus from agriculture to the entire food system, a wider range of stakeholders can be meaningfully involved in designing and assessing policies for agroecological transformation, thereby linking participation with the holism frame, which emphasizes the interconnectedness of elements in the agroecological food system (see below). Moreover, several authors argue that promoting multi-actor collaborations at the territorial scale, for instance in the form of food policy councils, is a particularly enabling factor in agroecological transformations (Lamine et al. 2019).

This frame has also been shaped by experiences with participatory governance in agroecology. A widely cited institutional example took place in Brazil, where the official integration of agroecology into public policy and discourse was shaped by a long history of interactions between the state, social movements, agricultural producers and researchers (Schmitt et al. 2017). This social dialogue played a key role, both in building convergence within civil society around a shared framing of agroecology and in proactively shaping the state's understanding that the development of agroecology requires a state-civil society dialogue. It led to the adoption of the National Policy on Agroecology and Organic Production (PNAPO) and the associated plans guiding its implementation.

FAO too considers participatory, 'responsible', governance as key to agroecological transitions (FAO 2018a). It argues that transparent, accountable and inclusive governance is required at multiple scales, for example to ensure equitable access to nature, including land. Further discursive links can be made between participation and other domains of agroecology transformation. Some associate agroecology with the commons, stressing collective approaches to environmental stewardship and knowledge (Nyeleni 2015; see also Chap. 4). Pimbert (2018a) calls for different forms of radical democracy and active citizenship in the governance of research and knowledge production for agroecology. Others emphasize the collaborative character of agroecological systems of exchange, embodied, for example, by cooperatives, participatory guarantee schemes and community-supported agriculture, which are often community-based, embrace participatory decision-making and strive towards inclusivity.

Although the participatory framing of agroecology generally enables transformation, the extent to which participation and participatory democracy are realized in practice, as part of an agroecological transition, is 
uneven. In this regard, Arnstein's ladder of citizens' participation is a useful reminder that participation can range from manipulation to more empowered forms in which people have control (Arnstein 1969). The field of participatory development and public participation in policymaking has long been characterized by narrow and perverted approaches to participation that are not guided by participants but rather by narrow agency within a pre-determined framework and are often used to justify and advance already existing agendas of governments, planners or NGOs (Cooke and Kothari 2001). As Raquel Ajates Gonzalez et al. (2018) point out, in the development of France's national strategy on agroecology, participation of civil society appeared to be limited to consultations on policy proposals, with limited influence on the final policy outcome, and an evaluative role along or at the end of the implementation process.

Further illustrating the co-optable nature of the participation frame, the World Economic Forum (WEF) and the Food Action Alliance that are advocating for the so-called Fourth Industrial Revolution (4IR) are also calling for 'transformative partnerships' and the need to create more sustainable and inclusive food systems. In this regard, 4IR actors claim to enable women entrepreneurs, youth and small farmers, particularly in Africa, to access 4IR technologies and new markets. Specifically, their inclusion in the world economy is to take place through digital platforms for food value chains (e.g. Technical Centre for Agricultural and Rural Cooperation (CTA) 2019). These platforms are virtual marketplaces that match supply and demand across the globe for agricultural inputs, equipment, products and services. In practice, therefore, the main vehicles for 4IR food system transformation are market-driven solutions led by the private sector and facilitated by the state, without meaningful spaces and means for other actors to participate in decision-making on this transformation. These conceptions of participation reinforce asymmetric power relations in the dominant regime. They are incompatible with political agroecology.

\section{Cultural Resonance}

Framing agroecology as a culturally appropriate, place-based form of agriculture and food provisioning enables transformation. The agroecological organic coffee movement in Chiapas and the Mesoamerican Campesino a Campesino $(\mathrm{CaC})$ network, for example, are inspired by cultural frames linking liberation theology, values of autonomy, love for Mother Earth, 
defence of territory and culture and the cosmovisions of Mesoamerican peoples (Mier y Terán Giménez Cacho et al. 2018). In the United States, black farmers' collectives are promoting 'Afro-ecology' as a form of agroecology shaped by Afro-indigenous life experience and traditions (Black Dirt Farm Collective 2016).

'Biocultural diversity' is another concept that researchers and communities use to describe agroecology's cultural embeddedness- the interrelatedness of biological and cultural diversity in territories (Pimbert and Borrini-Feyerabend 2019). In policy supporting agroecology, an example of cultural resonance is the 'New Andean Constitutionalism' in Ecuador and Bolivia. This approach embodies 'epistemologies of the South' (Santos 2015 ) — indigenous cosmovisions and knowledge systems — as the basis for governance, food sovereignty and agroecology (Schilling-Vacaflor 2011).

Beyond production, some groups are calling for "culturally appropriate diets' as part of agroecology (Baker et al. 2019; FAO 2018a) and, more broadly, for culturally diverse definitions of a 'good life'. They include movements for Ecological Swaraj in India, Eco-Ubuntu in South Africa and Buen Vivir in Latin America.

Although, as a frame, cultural resonance is largely enabling, some deploy it in ways that undermine political agroecology. Some practitioners of Zero Budget Natural Farming in India-which has been celebrated as an agroecological innovation-have adopted a Hindu nationalist stance, in which religious and ethnic minorities and people marked as lower caste are viewed as inferior (Bhattacharya 2017; Khadse et al. 2017). Cultural discourse that is prejudiced and racist clearly violates the principles of equity that underpin agroecology (see Chap. 8 on equity). In another case, working within the dominant regime, the Alliance for a Green Revolution in Africa (AGRA) declares on its website that "African farmers need uniquely African solutions" to sustainably increase their productivity and access markets. Here, the rhetoric of cultural resonance (African pride) obscures the fact that the AGRA website primarily advances Western technologies and corporate interests in Africa.

These examples clearly show how the notion of cultural resonance can also be deployed in superficial, disingenuous ways that go against the heart of agroecology, by strengthening xenophobic sentiments or advancing industrial agriculture. 


\section{Holism}

Agroecological transformation can be enabled when agroecology is incorporated into wider calls for holism-a frame emphasizing the interconnectedness of elements in the agroecological system. Holism reflects a significant break from sectoral thinking, which suggests that agroecology is solely about agriculture and only concerns farmers, and contrasts with reductionist thinking and compartmentalization. A holistic framing chimes with agroecology's embrace of complexity and interconnectedness as a way of triggering wider social transformation within the agri-food system.

In the Declaration of the International Forum on Agroecology (2015), social movements conceptualize agroecological transitions as cutting across multiple agricultural sectors and bridging political, economic and cultural dimensions of food systems. For researchers, this perspective implies adopting a transdisciplinary, participatory, action-oriented approach to investigation, combining the natural and social sciences with the local knowledge of practitioners and consumers (Méndez et al. 2015; see also Chap. 5). Linking the intersectoral nature of agroecology with the need to integrate related knowledge systems, researchers and social movements often emphasize that agroecology is simultaneously "a movement, a science, and a practice" (Wezel et al. 2009).

Systems, rather than sectoral, thinking has also been an important variant of this frame. FAO, for instance, calls for a systems vision on agricultural policy development that "maximizes synergies within the food system, mitigates negative externalities and minimizes harmful competition between agricultural sectors" as well as between agriculture and other sectors (FAO 2014, 2018c). In the same spirit, the International Panel of Experts on Sustainable Food Systems (IPES-Food 2019) advocates for an umbrella strategy for food system transformation in Europe that integrates policy areas currently handled by separate directorate generals and committees.

From a critical perspective, not all claims to holism lend themselves to a transformative agroecology; indeed, they may play a role in co-opting its radical potential. Several studies note that the governments of France (Ajates Gonzalez et al. 2018) and China (Shiming and Gliessman 2017) have both engaged in discourse and created policies that gesture towards holism. These have, however, been strongly shaped by a reductionist scientific and technical understanding of agroecology that aligns well with the dominant regime but lacks reference to intersectoral linkages and the 
socio-political aspects of agroecology. Further weakening the transformative potential of holism, proponents of the 4IR in food and agriculture are also calling for a 'system-wide' transformation based on the alignment of multiple actors for deploying 4IR technologies across the globe and enabling integrated value chain investments such as the Grow Africa programme (World Economic Forum (WEF) 2018). Although Grow Africa aims to facilitate cross-sector policy dialogue with the government, private sector, research and civil society, its ultimate aim is to transform African agriculture through private sector investment in specific agricultural commodity value chains (e.g. cassava in Nigeria, mango in Burkina Faso) and connect African farmers with national, regional and international markets. This approach puts the private sector in a privileged position and favours a market-led rather than a holistic agricultural transformation.

\section{LIVELIHOODS}

As a frame, livelihoods can either enable or disable a transformative agroecology. From an enabling perspective, this frame reveals how agroecology can strengthen the livelihoods and well-being of smallholder food producers, indigenous peoples, women and young people and how they in turn are well suited to advance agroecology. It also emphasizes agroecology's connections with the agency and autonomy of food producers, family farming as a way of life and the centrality of rural people's livelihoods (IPES-Food 2016; van Walsum et al. 2014). Agroecology is thus sharply contrasted with the dominant regime's dehumanizing, modernizing, urbanizing, capitalist logics in agriculture, where livelihoods are an externality or an indirect effect.

A wide range of actors deploy the livelihood frame to enable agroecology. Food sovereignty movements have long argued for the importance of farmers' agency and livelihoods in agroecology (Nyeleni 2015). La Via Campesina, for example, has emphasized the value of the peasant way of life (Desmarais 2008), invoked too in their framings of agroecology. Social movements and farming families often highlight how agroecology can improve farmers' livelihoods by helping them rely less on, or avoid, input and credit markets, expensive technologies and exploitative long supply chains (Rosset and Martinez-Torres 2012). Similarly, FAO recognizes that the multifunctionality of family farmers allows them to act holistically on multiple dimensions of agroecology. Their multiple functions include producing most of the world's food, acting as stewards of nature by preserving and developing biodiversity, preserving and sharing traditional 
knowledge, and contributing to the resilience of people and nature. Importantly, when empowered, they help strengthen the economic viability of rural areas (FAO 2018b).

This frame is also closely linked to knowledge, creativity and solidarity economy, an ethical and values-based approach to economic well-being that prioritizes the welfare of people and planet over profits and economic growth. Through this, it reveals how agroecology plays an important role in creating meaningful employment as well as fair livelihoods for food producers (FAO 2018a; Timmermann and Félix 2015; World Forum of Fisher Peoples (WFFP) 2017; see Chap. 6 on the systems of economic exchange domain). Relatedly, an emerging line of discourse associates agroecology with alternative definitions of well-being that include fair livelihoods such as de-growth and Buen Vivir (Kothari et al. 2015).

Prior to the 2018 election of Brazilian President Jair Bolsonaro, the institutional space for agroecology in the country had been opened up by the formal recognition of family farming as an economically viable form of agriculture-one that increased its social legitimacy and public visibility while contributing to the emergence of a discourse that strongly associated a political agroecology with family farmers (Lamine 2017). In addition, a recent empirical study of experiences across Europe emphasizes the economic potential of agroecology for sustaining livelihoods of family farmers (van der Ploeg et al. 2019).

The livelihoods frame, however, has also been disabling for a transformative agroecology. First, proponents of the corporate-led 4IR also claim to be opening up new employment opportunities and new markets for small farmers, particularly in Africa, by creating an inclusive digital environment (e.g. Technical Centre for Agricultural and Rural Cooperation (CTA) 2019). In this model, 'livelihood' is often reduced merely to income or economic returns-assuming that access to new markets will increase income and therefore increase farmers' ability to achieve food security by buying food-what Jahi Chappell (2018) has argued is a potential form of 'neo-productivism'. This approach, however, is incompatible with political agroecology on many levels. It creates dependency on expensive inputs, disenfranchises food producers as agents of change and focuses on the production of monocrops for global markets instead of the development of regional food systems, food producer agency and diverse, healthy diets.

Similarly, the livelihoods frame is also often flipped so that small-scale, family-based agriculture is trivialized in favour of a business-focused framing of livelihoods. This can demobilize food producers and rural 
communities interested in agroecology by preventing them from launching or expanding agroecological experiments. Such discursive frames often label peasants, traditional rural communities and traditional forms of agriculture as poor, backward, low quality, inefficient or unproductive, suggesting that agriculture is inherently a form of drudgery (Isgren 2016; Schneider 2015). At the same time, they may present large-scale producers and industrial forms of agriculture as modern, productive, tidy, entrepreneurial and representative of 'good' farming and insist that it is in farmers' and society's best interests to minimize the number of people unfortunate enough to be farmers.

In contemporary China, negative discourse on peasants (nongmin) and small-scale agriculture has justified and shaped agricultural policies that aim to reduce the number of peasants and promote agricultural modernization and urbanization through novel forms of industrialization (Schneider 2015; Si et al. 2018). Although claiming to enable small farmers' livelihoods, proponents of 4IR also aim, for example, to foster "a new breed of young ICT 'agripreneurs" (Technical Centre for Agricultural and Rural Cooperation (CTA) 2019, p. 10). This kind of framing attempts to minimize the assumed hardship and drudgery of farming by industrializing it and minimizing the number of people 'subjected' to it-rather than seeking to decrease the marginalization, monoculturalization, low pay and low respect often afforded to family farmers.

\section{Box 9.1 A spotlight on the problematic nature of the "Innovation} Frame" for political agroecology

The framing of agroecology as a sustainable or green innovation has taken hold over the past few years. While embraced by a wide range of actors, this frame can undermine the potential of a transformative agroecology for the following reasons:

(1) The innovation frame often reduces agroecology to its technical dimensions. It positions agroecology as one of multiple innovations in a wider toolbox containing purely technological approaches, rather than viewing it as an alternative paradigm and political transformation of the food system.

(2) Innovation is deeply tied to capitalist and neoliberal logics of economic development and productivism. Indicators of whether 


\section{Box 9.1 (continued)}

agroecology is innovative tend to be based on narrow productivity and profitability measures on individual farms and of individual crops. This marginalizes or erases all of the multiple functions (see Chapter 2, page 18) of agroecology, which are also qualitative, social and political.

(3) Discursively, innovation is often directly tied to modern technology and thus agroecology is often viewed as backward in this context.

In their recent report Agroecology and Other Innovations (2019), the High Level Panel of Experts on Food Security and Nutrition essentially argued for a demotion of the innovation frame, claiming instead that the value of "agroecology and other innovations" need to be assessed for their capacity to realize people's agency and rights. Within this significant global food policy process, proponents of a transformative agroecology were able to assert their power in reframing the debate and produce a high-profile UN report that centres a transformative framing of agroecology.

Source: Maughn and Anderson, Forthcoming Publication.

\section{Ecological Modernization}

Recognizing the ecological imperative to address the multiple crises in the food system, discursive frames that emphasize ecological modernization (EM) have gained international traction. Many calling for it are advocates of high-tech approaches to food system transformation, such as sustainable intensification, climate-smart agriculture and the 4IR (Pimbert 2015). As an approach to environmental policy-making that supports the dominant food system, EM describes an ecological restructuring of the capitalist political economy and the associated industrial food system (Dryzek 2013; Horlings and Marsden 2011).

Most who promote EM are in the private sector, science, government and multilateral organizations, and they perceive environmental degradation-caused in part by polluting, resource-intensive food and agriculture 
systems - as an impediment to continued, albeit greener, economic growth. This framing informs the European Commission's Bioeconomy Strategy, which aims to support "the modernisation and strengthening of the EU industrial base through the creation of new value chains and greener, more cost-effective industrial processes" (European Commission 2018; Levidow 2015).

EM is particularly disabling in the agroecology context because it appears to contribute to many of the immediate goals of the environmental movement-such as reducing pesticide use and increasing energy efficiency and the availability of mass-produced 'sustainable' food-through mostly technological solutions in large-scale agricultural systems. But such approaches do nothing to address the systemic, political and social underpinnings of the current crises. Through the EM frame, agroecology becomes pigeonholed as one small subset of a broader range of sustainable food system practices, rather than a transformative, even subversive, paradigm.

In France, for instance, government discourse has framed agroecology as an essentially economic rather than environmental policy and presented the environmental performance of farms, achieved through increased resource efficiency and reduced use of chemical inputs, as a lever for raising productivity and competitiveness and for generating further economic benefits. Similarly, in China the government has emphasized how 'ecological civilization' enables eco-agriculture, reflecting the EM-inspired view that environmental sustainability and economic growth can be reconciled (Loconto and Fouilleux 2019). As is the case in other countries, the Chinese government approaches citizens as potential consumers of green products and services, rather than as political agents of change.

Lummina Horlings and Terry Marsden (2011) observe that in past decades, the dominant food regime has privileged the pathway of a 'weak' EM frame, focusing on technological solutions for the sustainable use of natural resources. Sustainable intensification and the 4IR reflect this trend. Focusing on improving food availability and stability — and in line with the 'feed the world' frame (see below) as well as 'weak' EM-the discourse on sustainable intensification promotes emerging technological innovations (such as next-generation biotechnologies, robots and blockchain) to increase productivity 'sustainably' (Bernard and Lux 2016; HLPE 2019; see also Box 9.1 on innovation) and international trade. 
For instance, FAO $(2017,2019)$, the Global Forum for the Future of Agriculture (2020) and the WEF (which drives the 4IR) are using the EM frame to promote a market-driven, science-led food system transformation (World Economic Forum (WEF) 2018). The technologies promoted and the focus on international trade are disabling factors for agroecology. Another weakness in the EM frame is a view of nature as "supplier of resources", "a recycler of pollutants" and an enabler of convivial green lifestyles (Dryzek 2013, p. 170). Indigenous approaches to agroecology, as well as emerging research on agroecology and economic de-growth, also question the 'green growth' model of EM.

While countries practising stronger EM approaches have been opening up environmental policy-making to a wider range of actors, including green groups, John Dryzek (2013) concludes that this privilege is often limited to already empowered actors and 'reformist environmental groups' (see also the section 'Participation'). In France, for example, despite discursive commitment to bottom-up governance, several studies (Ajates Gonzalez et al. 2018; Lamine 2017) note the dominance of large farmers' unions, public research, technical institutes and agricultural chambers in shaping and implementing EM policy. This is incompatible with political agroecology that aims to empower traditionally excluded and marginalized groups.

\section{FeEd THE WORLd}

As a framing, the idea of feeding the world is often underpinned by an alarmist discourse on population growth, hunger and climate change. These serve to embed the emphasis on productivity as the key challenge in nourishing populations (IPES-Food 2016; Fouilleux et al. 2017).

The 'feed the world' frame is frequently used in conjunction with eyecatching statistics, also found in high-profile FAO publications, anticipating that world food production will have to increase by at least $50 \%$ by 2050 compared to 2012 levels, while in sub-Saharan Africa and South Asia, output will have to more than double (Tomlinson 2011). In China, Zhenzhong Si et al. (2018) argue that the 'feed China' narrative plays a similar role. This exclusive focus on short-term productivity almost entirely disables agroecology transformations by erasing multidimensional and long-term regenerative processes and functions. The 'feed the world' 
frame also promotes even more ecologically destructive production methods and downplays justice and distribution issues related to poverty and social inclusion, focusing even more intensely on industrialization and global trade as a means of addressing food insecurity.

Governments and private sector actors who deploy this frame often promote technological packages associated with the Green and Blue Revolutions, combined with liberalized international trade and underpinned by an ideological commitment to wealth and progress based on economic growth (IPES-Food 2016; Fouilleux et al. 2017; Tomlinson 2011).

Eve Fouilleux et al. (2017) note that social movements, particularly peasant groups, strongly oppose these mechanisms and 'solutions' but do not always disagree with the discourse on the need to produce more food. They frame family farming as the essential lever to nourishing local communities across the world, emphasizing not just productivity and availability but also food sovereignty, food and nutrition security, the right to food and food justice. However, the asymmetry in resources and access to powerful arenas where food policies are negotiated means that approaches aimed at increasing productivity prevail, thereby hampering agroecological transformations.

\section{REFERENCES}

Ajates Gonzalez, R., Thomas, J., \& Chang, M. (2018). Translating Agroecology into Policy: The Case of France and the United Kingdom. Sustainability, 10(8), 19.

Arnstein, S. R. (1969). A Ladder of Citizen Participation. Journal of the American Institute of planners, 35(4), 216-224.

Articulação Nacional de Agroecología (ANA). (2018). Sem Feminismo Não Há Agroecologia. IV Encontro Nacional de Agroecologia (ENA), Belo Horizonte, Brasil.

Baker, L., Gemmill-Herren, B., \& Leippert, F. (2019). Accelerating Transformations to Sustainable Food Systems. In Accelerating Transformations to Sustainable Food Systems: Beacons of Hope. Biovision Foundation and Global Alliance for the Future of Food.

Benford, R. D., \& Snow, D. A. (2000). Framing Processes and Social Movements: An Overview and Assessment. Annual Review of Sociology, 26(1), 611-639.

Bernard, B., \& Lux, A. (2016). How to Feed the World Sustainably: An Overview of the Discourse on Agroecology and Sustainable Intensification. Regional Environmental Change, 17(5), 1279-1290. 
Bezner Kerr, R., Hickey, C., Lupafya, E., \& Dakishoni, L. (2019). Repairing Rifts or Reproducing Inequalities? Agroecology, Food Sovereignty, and Gender Justice in Malawi. The Journal of Peasant Studies, 46(7), 1499-1518.

Bhattacharya, N. (2017). Food Sovereignty and Agro-ecology in Karnataka: Interplay of Discourses, Identities, and Practices. Development in Practice, $27(4), 544-554$.

Black Dirt Farm Collective. (2016). Afro-ecology: Cultivating Connectivity.

Chappell, M. J. (2018). Beginning to End Hunger: Food and the Environment in 332 Belo Horizonte, Brazil, and Beyond. Oakland: University of California Press.

Claeys, P. (2015). Food Sovereignty and the Recognition of New Rights for Peasants at the UN: A Critical Overview of La Via Campesina's Rights Claims over the Last 20 Years. Globalizations, 12(4), 452-465.

Cooke, B., \& Kothari, U. (2001). Participation: The New Tyranny? London: Zed.

Desmarais, A. A. (2008). The Power of Peasants: Reflections on the Meanings of La Vía Campesina. Journal of Rural Studies, 24(2), 138-149.

Dryzek, J. S. (2013). The Politics of the Earth: Environmental Discourses. Oxford: Oxford University Press.

European Commission. (2018). A Sustainable Bioeconomy for Europe: Strengthening the Connection between Economy, Society and the Environment. Brussels: European Commission.

FAO. (2014). Building a Common Vision for Sustainable Food and Agriculture. Principles and Approaches (p. 50). Rome: FAO.

FAO. (2017). Climate Smart Agriculture Sourcebook (2nd ed.).

FAO. (2018a). The 10 Elements of Agroecology. Rome: FAO.

FAO. (2018b). FAO's Work on Agroecology. A Pathway to Achieving the SDGs. Rome: FAO.

FAO. (2018c). Scaling up Agroecology Initiative: Transforming Food and Agricultural Systems in Support of the SDGs. Rome: FAO.

FAO. (2019). Unlocking the Potential of Agricultural Innovation to Achieve the Sustainable Development Goals. In J. Ruane (Ed.), Proceedings of the International Symposium on Agricultural Innovation for Family Farmers (p. 120). Rome.

Fouilleux, E., Bricas, N., \& Alpha, A. (2017). 'Feeding 9 billion people': Global Food Security Debates and the Productionist Trap. Journal of European Public Policy, 24(11), 1658-1677.

Friends of the Earth International. (2015). Agroecology and Climate Justice: A People's Guide to Paris and Beyond.

Geels, F. W., \& Verhees, B. (2011). Cultural Legitimacy and Framing Struggles in Innovation Journeys: A Cultural-Performative Perspective and a Case Study of Dutch Nuclear Energy (1945-1986). Technological Forecasting and Social Change, 78(6), 910-930. 
Giraldo, O. F., \& Rosset, P. M. (2018). Agroecology as a Territory in Dispute: Between Institutionality and Social Movements. The Journal of Peasant Studies, $45(3), 545-564$.

Global Forum for the Future of Agriculture (GFFA). (2020). Food for All! Trade for Secure, Diverse and Sustainable Nutrition. Communiqué 2020.

HLPE. (2019). Agroecological and Other Innovative Approaches for Sustainable Agriculture and Food Systems that Enhance Food Security and Nutrition. Rome: High Level Panel of Experts on Food Security and Nutrition of the Committee on World Food Security.

Holt-Giménez, E., \& Altieri, M. A. (2013). Agroecology, Food Sovereignty, and the New Green Revolution. Agroecology and Sustainable Food Systems, 37(1), 90-102.

Horlings, L. G., \& Marsden, T. K. (2011). Towards the Real Green Revolution? Exploring the Conceptual Dimensions of a New Ecological Modernisation of Agriculture that Could 'feed the world'. Global Environmental Change, $21(2), 441-452$.

IPES-Food. (2016). From Uniformity to Diversity: A Paradigm Shift from Industrial Agriculture to Diversified Agroecological Systems. International Panel of Experts on Sustainable Food Systems (IPES).

IPES-Food. (2019). Towards a Common Food Policy for the EU.

Isgren, E. (2016). No Quick Fixes: Four Interacting Constraints to Advancing Agroecology in Uganda. International Journal of Agricultural Sustainability, $14(4), 428-447$.

Khadse, A., Rosset, P. M., Morales, H., \& Ferguson, B. G. (2017). Taking Agroecology to Scale: The Zero Budget Natural Farming Peasant Movement in Karnataka, India. The Journal of Peasant Studies, 45(1), 192-219.

Kothari, A., Demaria, F., \& Acosta, A. (2015). Buen Vivir, Degrowth and Ecological Swaraj: Alternatives to Sustainable Development and the Green Economy. Development, 57(3-4), 362-375.

La Via Campesina. (2018). La Via Campesina in Action for Climate Justice. Ecology, 44(6), 1-32.

Lamine, C. (2017). La fabrique sociale de l'écologisation de l'agriculture. Marseille: Éditions la Discussion.

Lamine, C., Magda, D., \& Amiot, M.-J. (2019). Crossing Sociological, Ecological, and Nutritional Perspectives on Agrifood Systems Transitions: Towards a Transdisciplinary Territorial Approach. Sustainability, 11(5), 1284.

Levidow, L. (2015). European Transitions Towards a Corporate-environmental Food Regime: Agroecological Incorporation or Contestation? Journal of Rural Studies, 40, 76-89.

Loconto, A. M., \& Fouilleux, E. (2019). Defining Agroecology. The International Journal of Sociology of Agriculture and Food, 25(2), 116-137. 
Maughan, C., Anderson, C., \& Kneafsey, M. (2020). A Five-Point Framework for Reading for Social Justice: A Case Study of Food Policy Discourse in the Context of Brexit Britain. Journal of Agriculture, Food Systems, and Community Development, 9, 1-20.

Maughan, C., \& Anderson, C. R. (Forthcoming). The Implications of the Innovation Agenda for Agroecology: A Case Study of the Agroecology Process at the U.N.

Méndez, V. E., Bacon, C. M., Cohen, R., \& Gliessman, S. R. (2015). Agroecology: A Transdisciplinary, Participatory and Action-oriented Approach. Roca Baton: CRC Press.

Mier y Terán Giménez Cacho, M., Giraldo, O. F., Aldasoro, M., Morales, H., Ferguson, B. G., Rosset, P., et al. (2018). Bringing Agroecology to Scale: Key Drivers and Emblematic Cases. Agroecology and Sustainable Food Systems, 42(6), 637-665.

Nyeleni. (2015). Declaration of the International Forum for Agroecology.

Nyeleni Movement for Food Sovereignty. (2007). Nyéléni Declaration for Food Sovereignty.

Pimbert, M. P. (2015). Agroecology as an Alternative Vision to Conventional Development and Climate-Smart Agriculture. Development, 58(2), 286-298.

Pimbert, M. P. (2018a). Democratizing Knowledge and Ways of Knowing for Food Sovereignty, Agroecology and Biocultural Diversity. In M. P. Pimbert (Ed.), Food Sovereignty, Agroecology and Biocultural Diversity. Constructing and Contesting Knowledge (pp. 259-321). London: Routledge.

Pimbert, M. P. (2018b). Food Sovereignty, Agroecology and Biocultural Diversity: Constructing and Contesting Knowledge. London: Routledge.

Pimbert, M. P., \& Borrini-Feyerabend, G. (2019). Nourishing Life-Territories of Life and Food Sovereignty (Policy Brief of the ICCA Consortium no. 6): The ICCA Consortium, Centre for Agroecology, Water and Resilience at Coventry University (UK) and CENESTA (Iran).

Rivera Ferre, M. G. (2018). The Resignification Process of Agroecology: Competing Narratives from Governments, Civil Society and Intergovernmental Organizations. Agroecology and Sustainable Food Systems, 42(6), 666-685.

Rosset, P. M., \& Martinez-Torres, M. E. (2012). Rural Social Movements and Agroecology: Context, Theory, and Process. Ecology and Society, 17(3), 17.

Santos, B. d. S. (2015). Epistemologies of the South: Justice Against Epistemicide. New York: Routledge.

Schilling-Vacaflor, A. (2011). Bolivia's New Constitution: Towards Participatory Democracy and Political Pluralism? Revista Europea de Estudios Latinoamericanos $y$ del Caribe/European Review of Latin American and Caribbean Studies, 90, 3-22. 
Schmitt, C., Niederle, P., Ávila, M., Sabourin, E., Petersen, P., Silveira, L., et al. (2017). A experiência brasileira de construção de políticas públicas em favor da agroecologia. In Politicas Públicas a favor de la Agroecología en América Latina y el Caribe. Porto Alegre: Red Políticas Publicas en América Latina y el Caribe (PP-AL) \& FAO.

Schneider, M. (2015). What, Then, Is a Chinese Peasant? Nongmin Discourses and Agroindustrialization in Contemporary China. Agriculture and Human Values, 32(2), 331-346.

Schwendler, S. F., \& Thompson, L. A. (2017). An Education in Gender and Agroecology in Brazil's Landless Rural Workers' Movement. Gender and Education, 29(1), 100-114.

Shiming, L., \& Gliessman, S. R. (2017). Agroecology in China: Science, Practice, and Sustainable Management. CRC Press.

Si, Z., Koberinski, J., \& Scott, S. (2018). Shifting from Industrial Agriculture to Diversified Agroecological Systems in China. Report prepared for IPES Food.

Steinberg, M. W. (1998). Tilting the Frame: Considerations on Collective Action Framing from a Discursive Turn. Theory and Society, 27(6), 845-872.

Technical Centre for Agricultural and Rural Cooperation (CTA). (2019). The Digitalisation of African Agriculture Report 2018-2019. Written by: Michael Tsan, Swetha Totapally, Michael Hailu and Benjamin Addom. Netherlands: CTA.

Timmermann, C., \& Félix, G. F. (2015). Agroecology as a Vehicle for Contributive Justice. Agriculture and Human Values, 32(3), 523-538.

Tomlinson, I. (2011). Doubling Food Production to Feed the 9 Billion: A Critical Perspective on a Key Discourse of Food Security in the UK. Journal of Rural Studies, 29(0), 81-90.

UNDROP, 2018. The United Nations declaration on the Rights of Peasants and Other People Working in Rural Areas [available at http://ap.ohchr.org/documenta/dpage_e.aspx?ai=A/hrC/39/L.16]

van der Ploeg, J. D., Barjolle, D., Bruil, J., Brunori, G., Costa Madureira, L. M., Dessein, J., et al. (2019). The Economic Potential of Agroecology: Empirical Evidence from Europe. Journal of Rural Studies, 71, 46-61.

van Walsum, E., Bruil, J., \& Pascieznick, N. (2014). Unlocking the Potential of Family Farmers with Agroecology (pp. 42-45). Deep Roots, FAO and Tudor Rose.

Wezel, A., Bellon, S., Doré, T., Francis, C., Vallod, D., \& David, C. (2009). Agroecology as a Science, a Movement and a Practice. A Review. Agronomy for Sustainable Development, 29(4), 503-515. 
World Economic Forum (WEF). (2018). Innovation with a Purpose: The Role of Technology Innovation in Accelerating Food Systems Transformations.

World Forum of Fisher Peoples (WFFP). (2017). Agroecology and Food Sovereignty in Small-Scale Fisheries. Indonesia.

Open Access This chapter is licensed under the terms of the Creative Commons Attribution 4.0 International License (http://creativecommons.org/licenses/ by $/ 4.0 /$ ), which permits use, sharing, adaptation, distribution and reproduction in any medium or format, as long as you give appropriate credit to the original author(s) and the source, provide a link to the Creative Commons licence and indicate if changes were made.

The images or other third party material in this chapter are included in the chapter's Creative Commons licence, unless indicated otherwise in a credit line to the material. If material is not included in the chapter's Creative Commons licence and your intended use is not permitted by statutory regulation or exceeds the permitted use, you will need to obtain permission directly from the copyright holder.

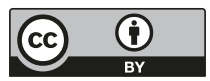

